\title{
Şanlıurfa ilinde besiye alınmış farklı sığır ırklarının besi performanslarının ve karkas özelliklerinin karşılaştırılması
}

\section{The comparison of fattening performance and carcass characteristics of different cattle breeds raised in Sanliurfa province}

\author{
Ayşe PINARBAŞI ${ }^{1}$ iD Kemal YAZGAN $^{1 *}$ iD \\ ${ }^{1}$ Harran üniversitesi Ziraat Fakültesi Zootekni Bölümü, Şanlıurfa
}

To cite this article:

Pınarbaşı, A. \& Yazgan, K. (2020). Şanlıurfa ilinde besiye alınmış farklı sığır ırklarının besi performanslarının ve karkas özelliklerinin

karşılaştırılması. Harran Tarım ve Gıda Bilimleri Dergisi, 24(2):212-221.

DOI: $10.29050 /$ harranziraat.669266

Address for Correspondence: Kemal YAZGAN

e-mail:

kyazgan@harran.edu.tr
Öz

Bu çalışmada Şanlıurfa ilinde yetiştirilen Siyah Alaca, Siyah Alaca melezi, Simental, Simental melezi, Esmer, Esmer melezi, Şarole ve Yerli Kara melezi ırkı sığırlara ait besi performansları ile karkas özellikleri (yağsız sıcak karkas ağırlığı ve karkas randımanları) araştırılmıştır. Araştırmanın veri setini Şanlıurfa ilinde özel bir işletmeden elde edilen tartım ve sıcak karkas ağırıkları oluşturmuştur. Kesim ağırıkları, yağsız sıcak karkas ağırlıkları, karkas randımanı ve günlük canlı ağırlık artışı sırasıyla Simental için 533.55 $\pm 5.799,330.5 \pm 3.544$, $0.56 \pm 0.001$ ve $1.26 \pm 0.019 \mathrm{~kg}$, Siyah Alaca için $527.01 \pm 7.868,321.01 \pm 4.80,0.55 \pm 0.002$ ve $1.24 \pm 0.027 \mathrm{~kg}$, Siyah Alaca Melezi için $522.78 \pm 9.575,323.64 \pm 6.152,0.56 \pm 0.003$ ve $1.22 \pm 0.032 \mathrm{~kg}$, Şarole için $522.86 \pm 11.996,323.22 \pm 7.333,0.56 \pm 0.003$ ve $1.22 \pm 0.036 \mathrm{~kg}$, Simental melezi için $519.58 \pm 6.361,318.85 \pm 3.985,0.56 \pm 0.002$ ve $1.21 \pm 0.021 \mathrm{~kg}$, Esmer Melezi için $507.35 \pm 6.602,315.26 \pm 3.8610 .56 \pm 0.002$ ve $1.17 \pm 0.021 \mathrm{~kg}$, Yerli Kara melezi için $502.15 \pm 8.253,311.24 \pm 4.97,0.56 \pm 0.002$ ve $1.15 \pm 0.026 \mathrm{~kg}$ ve son olarak Esmer için $491.27 \pm 4.705,306.21 \pm 2.783,0.56 \pm 0.003$ ve $1.12 \pm 0.015 \mathrm{~kg}$ 'dır. Araştırma sonunda kesim ağırlıkları, yağsız sıcak karkas ağırlıkları ve günlük canlı ağırlık artışı bakımından Simental, Simental melezi, Şarole, Siyah Alaca ve Siyah Alaca melezi ırkı sığırların Yerli Kara melezi, Esmer ve Esmer melezi ırklardan yüksek performans gösterdiği saptanmıştır $(P<0.05)$. Karkas randımanı bakımından ise Siyah Alaca ırkı sığırlar diğer ırklardan daha düşük performans göstermişlerdir $(P<0.05)$. Tüm bu verilerin ışığında Şanlıurfa koşullarında yetiştiricilere üzerinde durulan tüm parametreler göz önünde bulundurulduğunda yoğun besicilikte Simental, Simental melezi, Şarole, Siyah Alaca melezi gibi sığır ırklarını kullanmaları önerilebilir.

Anahtar Kelimeler: Siyah Alaca, Simental, Şarole, Besi performansı, Karkas özellikleri

\section{ABSTRACT}

This research was carried out to examine the fattening performance and carcass characteristic such as hot carcass weight and dressing percentage of Holstein and crossbreed Holstein, Simmental and crossbreed Simmental, Brown Swiss and crossbreed Brown Swiss, Charolais and crossbreed Native Anatolian Black cattle. The data set consist of live weight and hot carcass weight records obtained from a commercial farm placed in Sanliurfa province. Slaughter live weights, hot carcass weights, dressing percentage and daily live weight gains were detected as 533.55 $\pm 5.799,330.5 \pm 3.544,0.56 \pm 0.001$ and $1.26 \pm 0.019 \mathrm{~kg}$ for Simmental, $527.01 \pm 7.868,321.01 \pm 4.80,0.55 \pm 0.002$ and $1.24 \pm 0.027 \mathrm{~kg}$, for Holstein, $522.78 \pm 9.575,323.64 \pm 6.152,0.56 \pm 0.003$ and $1.22 \pm 0.032 \mathrm{~kg}$ for crossbreed Holstein, $522.86 \pm 11.996,323.22 \pm 7.333,0.56 \pm 0.003$ and $1.22 \pm 0.036 \mathrm{~kg}$ for Charolais, $519.58 \pm 6.361,318.85 \pm 3.985,0.56 \pm 0.002$ and $1.21 \pm 0.021 \mathrm{~kg}$ for crossbreed Simmental, $507.35 \pm 6.602,315.26 \pm 3.8610 .56 \pm 0.002$ and $1.17 \pm 0.021 \mathrm{~kg}$ for crossbreed Brown Swiss, $502.15 \pm 8.253,311.24 \pm 4.97,0.56 \pm 0.002$ and $1.15 \pm 0.026 \mathrm{~kg}$ for crossbreed Native 
Anatolian Black and finally, 491.27 $\pm 4.705,306.21 \pm 2.783,0.56 \pm 0.003$ and $1.12 \pm 0.015 \mathrm{~kg}$ for Brown Swiss cattle respectively. At the end of this research, considering the slaughter live weights, hot carcass weights and daily live weight gains, determined that Simmental, crossbreed Simmental, Charolais, Holstein and crossbreed Holstein were superior than crossbreed Native Anatolian Black, Brown Swiss and cross breed Brown Swiss $(P<0.05)$. However, considering the dressing percentage of cattle breeds, Holstein had lover percentage than the others $(P<0.05)$. According to these results, for intensive fattening activity, it is advisable to cattle breeders that using Simmental, crossbreed Simmental, Charolais, crossbreed Holstein for the under Sanliurfa conditions.

Key Words: Holstein, Simmental, Charolais, Fattening performance, Carcass characteristic

\section{Giriş}

Sığır 8.000-10.000 yıl önce evcilleştirilerek süt, et, iş, deri ve gübre gibi çeşitli verimleri ile insan refahına katkıda bulunmaktadır (Şekerden ve Özkütük, 1997). Sığııın ruminant olarak selüloz içeriği yüksek olan kaba yemleri çok iyi bir şekilde değerlendirebilmesi insan beslenmesinde sığııın vazgeçilmez bir materyal olmasını sağlamıştır. İnsanların değişen talepleri ile orantılı olarak sığırların verimlerinde de değişiklikler meydana getirilmiştir.

Sığır besisi kabaca çeşitli yaşlardaki sığırlara canlı ağırlık, dolayısıyla kas yapısında artış sağlamak amacıyla yapılan bir faaliyettir. Eğer bu tanıma tamamen uyulursa normal büyüme de besi olarak nitelenir. Oysa beside amaç et üretimidir. Bu nedenle sığır besisi, bir sığırdan mümkün olan en kısa sürede, en fazla eti, en ekonomik şekilde üretme çabalarının tümü olarak tanımlanabilir. Farklı işlemlerden geçirilmiş tahıllarla beslenen ruminantlarda yapılan araştırmalar incelendiğinde, hayvanlarda canlı ağılık artışı ve yem tüketimi bakımından birbirinden farklı sonuçlar elde edildiği görülmektedir (Toprak ve ark.,2018).

Ülkemizde besi materyali olarak Doğu Anadolu Kırmızısı, Yerli Kara, Güney Anadolu Kırmızısı, Esmer, Simental, Siyah Alaca ve bunların birbirleriyle çeşitli düzeydeki melezleri besi materyali olarak kullanılmaktadır. Bunlara son yıllarda Angus, Şarole, Hereford gibi etçi sığır ırkları da dahil olmaya başlamıştır. Cumhuriyetin ilk yıllarında yaşı hayvanların meraya dayalı olarak semirtilip kesilmeleri ile sağlanan etin her anlamda yetersizliği kavranmış olup bir yandan besi işletmelerinin kurulması teşvik edilirken diğer yandan da besiye uygun hayvan materyali seçimi hız kazanmıştır (Akman, 1998).
Şanlıurfa'nın diğer birçok sektörde olduğu gibi hayvancılık alanında da açığa çıkarılmayı bekleyen büyük bir potansiyeli vardır. Bölgede zaten yapılmakta olan küçükbaş hayvancılık faaliyetleri, devlet destekleri ile son yıllarda kurulmaya başlanan modern büyükbaş hayvancılık tesisleri ile birleşince bölgede hayvancılık sektörünün görünümü değişmeye başlamıştır. Buna ek olarak, yeniden düzenlenen devlet teşviklerince 6 . Bölge olarak sınıflandırılan Şanlıurfa'nın hayvancılık sektörüne sunduğu karşılaştırmalı avantajları da önemli ölçüde artmıştır (Anonim, 2013). İldeki büyükbaş hayvan varlığı 2013 yılı itibariyle yaklaşık 197.000 başa ulaşmıştır (Anonim, 2013). Bu rakam Türkiye'deki toplam büyükbaş varlığının yaklaşık $\% 1$ 'ini oluşturmaktadır.

Beside karlılık yem ve hayvan materyalini en uygun şekilde kullanmakla arttırılabilir. Beside kullanılacak hayvanların ırkları yem değerlendirmeye direk etkili olduğu için beside karlılığı etkileyen en önemli unsurlardan biridir.

Türkiye'de mevcut ırk veya tipler arasında, bu faktörler bakımlardan önemli farklılıklar vardır. Örneğin Yerli Kara mevcut en iyi yemlerle besleniyor olsa bile, aynı koşullarda yetişen Siyah Alaca ırkı sığırlar kadar günlük canlı ağırlık artışı sağlayamamaktadır. Buna karşılık, iyi koşullarda 1.400 gr civarında günlük canlı ağırlık artışı sağlayabilen Siyah Alaca kötü koşullarda, örneğin, kötü meralarda belki Yerli Karadan da geri kalabilecektir (Akman, 1999).

Kızıl ve Aydoğan (2014), canlı ağılık, deri, baş, ayak, akciğer, kalp, karaciğer, dalak, testis, penis, iç yağı ağırlıkları ve 18 karkas özelliğinin karşılaştırılmasında Kültür ırkları (Simmental, Siyah Alaca, Esmer) ile yerli ırklar (Yerli Kara, Doğu Anadolu Kırmızısı, Güneydoğu Anadolu Kırmızısı) ve melezler (Yerli Kara $\times$ Esmer) arasındaki farkların, 
kültür ırkları yönünde yüksek oranda önemli olduğunu, Siyah Alaca ve Esmer ırklarının, deri ağırlığı, pirzola ağırlığı ve kemik oranı haricindeki tüm özelliklerde birbirine benzer değerlere sahip olduklarını, Yerli Kara ırkının, yerli ırklar arasında kemik oranı haricindeki tüm özelliklerde en düşük değerlere sahip olduğunu, Doğu Anadolu Kırmızısı ve Güneydoğu Anadolu Kırmızısı sığırların ise, incelenmiş olan tüm özellikler yönünden benzer değerlere sahip olduklarını bildirmişlerdir.

Haiger ve Knaus (2010) 660 kg olarak ölçülen Avusturya Simental tosunlarının besi sonu ağırlığının 565 kg olarak ölçülen Siyah-Alaca tosunlarından daha yüksek olduğunu tespit etmişlerdir. Simental tosunların kesim performanslarının neredeyse tamamı açısından Siyah-Alacalardan üstün olduklarını, SiyahAlacaların $1 \mathrm{~kg}$ canlı ağırlık artışı için yem enerji gereksiniminin Simental ırkı sığırlardan \%8 yüksek olduğunu, günlük canlı ağırlık artışının ise \%12 daha düşük olduğunu bildirmişlerdir. Böylece Simentallerden sağlanan gelirin Siyah-Alacalardan \%26 daha yüksek olduğu sonucuna varmışlardır. Diğer taraftan Çatıkkaş (2015), Esmer, Simental ve Siyah Alaca ırkı sığırlarda bu ırklardan herhangi birinin seçilmesinin et kalite özellikleri ile kesim ve karkas özellikleri açısından önemli bir farklılık oluşturmayacağını bildirmiştir. Akbulut ve Tüzemen (1994) tarafından yapılan bir başka çalışmada ise Esmer, Siyah Alaca ve Sarı Alaca tosunların beside günlük ağırlık artışlarının sırası ile $0.941 \pm 0.04,0.909 \pm 0.08$ ve $0.951 \pm 0.04 \mathrm{~kg}$, yemden yararlanma derecelerinin de aynı sıraya göre $6.390 \pm 0.28,6.739 \pm 0.62$ ve $6.273 \pm 0.24 \mathrm{~kg}$ olduğu tespit edilmiştir.

Duru ve Sak (2017) Simental ırkı sığırlarda yağsız sıcak karkas ağırığını 303.4 kg, günlük canlı ağırlık artışını $1.3629 \mathrm{~kg}$ ve kesim ağırlığını 523.4 kg olarak bildirmişlerdir.

Çiçek ve ark. (2010), Montofon melezi sığırlarda 180 günlük besi sonrasında ortalama günlük olarak sağlanan canlı ağırlık artışının $1.36 \mathrm{~kg}$, besi sonu canlı ağırlığının $495.10 \mathrm{~kg}$, yemden yararlanma oranının da kuru madde cinsinden 6.62 olduğunu belirlemişlerdir. Bununla birlikte Tüzemen (1995), 10-15 aylık Esmer tosunların günlük canlı ağırlık artışlarını $1.165 \mathrm{~kg}$ olarak tespit etmiştir.

Koç ve Akman (2003), ithal edilmiş Siyah Alaca tosunlarda günlük canlı ağırlık artışını 964.3 \pm 59.53 ila 1083.9 $\pm 93.81 \mathrm{gr}$ olarak belirlemişler benzer şekilde ilgü ve Güneş (2002), Siyah Alaca ırkı sığırlarda günlük canlı ağırlık artışı değerlerini 1023.6 g olarak hesaplamışlardır.

Güngör ve ark. (2004), Siyah Alaca ve melez grupları arasında günlük ortalama canlı ağırlık artışı, yem tüketimi ve yemden yararlanma bakımından bir fark olmadığını, Siyah Alaca $x$ Piedmont melezlerinde sıcak ve soğuk karkas ağırlıkları ve randıman değerlerinin Siyah Alaca sığırlardan önemli derecede yüksek olduğunu, ancak Siyah Alaca $x$ Limuzin melezi ile önemli bir farkı olmadığını M. longissimus dorsi alanının Siyah Alaca $x$ Piedmont ve Siyah Alaca $x$ Limuzin melezlerinde en yüksek değerde olduğunu saptamışlardır.

Sağsöz ve ark. (2005) Şarole ırkı sığırların günlük canlı ağırlık artış değerini $0.885 \pm 0.05$ olarak tespit etmişlerdir.

Bu çalışmada Şanlıurfa'da entansif koşullarda yetiştiriciliği yapılan Siyah Alaca, Simental, Esmer ile bunların değişik düzeydeki melezleri ve buna ilaveten Yerli Kara melezleri ve Şarole gibi ırkların kesim ağırlığı, yağsız sıcak karkas ağırlığı, günlük canlı ağırlık artışı ve karkas randımanı gibi özellikler bakımından karşılaştırılması amaçlanmıştır.

\section{Materyal ve Metot}

\section{Hayvan ve deneme materyali}

Çalışmanın materyalini Şanlıurfa ilinde bulunan özel bir besi işletmesinden alınan ve hiç bir sağlık probleminin bulunmadığı gözlenen 113 baş Siyah Alaca, 71 baş Siyah Alaca melezi, 160 baş Esmer, 92 baş Esmer melezi, 144 baş Simental, 115 baş Simental melezi, 80 baş Yerli Kara melezi ve 41 baş Şarole sığırlarına ait muhtelif kayıtlar oluşturmuştur. Bu kayıtlar cinsiyet, stok numarası, bakanlık numarası, satın alındığı il, ırk, yaş, işletmeye giriş tarihi ve ağırlıkları, karantinaya giriş tarihi ve ağırlığı, karantinadaki canlı ağırlık kaybı, tartım tarihleri ve tartım ağırlıkları, kesim nedeni ve kesim esnasında karkastan böbrek ve perde 
yağları, iç yağlar ve gövde yağı ayrıldıktan sonra kalan kısım olarak adlandırılan yağsız sıcak karkas ağırlık değerlerinden oluşmaktadır. Ayrıca kayıtlarda beside kalma süresi ve besi başı ağırlıkları da bulunmaktadır (Çizelge 1.).

Çalışmada kullanılan verim kayıtlarının elde edildiği işletme $37^{\circ} 0,8^{\prime}$ enlem ve $39^{\circ} 0,5^{\prime}$ boylam üzerinde olup deniz seviyesinden yüksekliği 547 metredir. Araştırmada kullanılan verilerin elde edildiği işletmenin bulunduğu bölgede tartım işlemlerinin gerçekleştirilip kayıt altına alındığı dönemde bölge yıllık ortalaman $445.1 \mathrm{~kg} / \mathrm{m}^{2}$ yağış almıştır. Çalışma süresince bölgedeki yıllık ortalama sıcaklık $18 \mathrm{C}^{\circ}$, yıllık en düşük sıcaklık 2.5 $C^{\circ}$ (Ocak), en yüksek sıcaklık $38.7 \mathrm{C}^{\circ}$ (Temmuz) olarak kaydedilmiştir. İşletme toplam 13.000 hayvan barındırma kapasitesine sahiptir.
Hayvanlar kaşınmaları için özel aparat bulundurulan bölmelerde 9 ila 10 baş olacak şekilde ve materyali $0.5 \mathrm{~mm}$ kalınlığında beyaz renk trepezoidal olan ve yerden yüksekliği 4.20 ila 8 metre arasında değişen gölgelikler altında barındırımıştır. Yaz aylarının çok sıcak günlerinde hayvanlara duş uygulaması yapılmıştır. Hayvanlara kastrasyon işlemi gerçekleştirilmemiştir. Serbest yemleme biçimi uygulanmış olup hayvanlar arpa, mısır, soya küspesi, pamuk tohumu küspesi, buğday küspesi, ayçiçeği tohumu küspesi, buğday samanı, mısır kepeği, buğday ve mısır silajı, vitamin, mermer tozu, mineral ön karma ve tuzdan oluşan yaklaşık olarak $2666 \mathrm{Kcal} \mathrm{ME} / \mathrm{kg}$ ve \%13.1 ham protein içeren rasyonla beslenmişlerdir. Besi süresince rasyondaki enerji ve protein düzeyi değişmemiştir.

Çizelge 1. Araştırmada kullanılan veri setine ait tanıtıcı istatistikler

Table 1. Descriptive statistic of the data set used in the research

\begin{tabular}{|c|c|c|c|c|c|}
\hline & & Besi başı ağırlığı (kg) & & Besi süresi (Gün) & \\
\hline Irk & $\mathrm{N}$ & $(\bar{X} \pm \mathrm{S} \bar{x})$ & CV & $(\bar{X} \pm \mathrm{S} \bar{x})$ & CV \\
\hline SA & 113 & $259.45 \pm 4.362$ & 17.827 & $305.19 \pm 4.109$ & 14.313 \\
\hline SAM & 71 & $223.00 \pm 5.837$ & 19.746 & $302.16 \pm 5.837$ & 16.279 \\
\hline $\mathrm{E}$ & 160 & $187.35 \pm 3.158$ & 21.325 & $301.21 \pm 1.972$ & 8.284 \\
\hline EM & 92 & $194.13 \pm 4.532$ & 21.106 & $322.91 \pm 4.832$ & 14.355 \\
\hline$S$ & 144 & $197.24 \pm 3.568$ & 21.709 & $300.72 \pm 3.258$ & 13.003 \\
\hline SM & 115 & $203.13 \pm 3.998$ & 21.106 & $294.58 \pm 3.470$ & 12.635 \\
\hline YKM & 41 & $184.82 \pm 5.797$ & 20.083 & $323.12 \pm 6.569$ & 13.017 \\
\hline Ş & 80 & $219.25 \pm 4.832$ & 19.741 & $313.28 \pm 5.497$ & 15.696 \\
\hline
\end{tabular}

SA: Siyah Alaca, SAM: Siyah Alaca Melezi, E: Esmer, EM: Esmer Melezi, S: Simental, SM: Simental Melezi, YKM: Yerli Kara melezi, Ş: Şarole, CV: Varyasyon katsayısı.

Bu kayıtlar tek tek incelenerek söz konusu hayvanlara ilişkin karkas randımanı, günlük canlı ağırlık artışı gibi değerler hesaplanmıştır. Bu hesaplamalar yapılırken aşağıdaki eşitliklerden yararlanılmıştır (Eşitlik 1 ve 2).

Karkas randımanı $=\frac{\text { Yağsız sıcak karkas ağırlı̆̆ı }}{\text { Kesim ağırlığı }} \times 100$

Günlük canlı ağırlık artışı $=\frac{\text { Besi sonu ağlığı-Besi başı ağırlı̆̆ı }}{\text { Besi süresi }}$

Söz konusu işletmede hayvanlar ırk faktöründen bağımsız olarak farklı mevsimlerde besiye alınıp farklı sürelerde beside tutulmuşlardır. Bundan dolayı veri setinde hayvanların ırk bazında kesim ağırlığı, yağsız sıcak karkas ağırlığı, karkas randımanı ve günlük canlı ağırlık artışı gibi verim parametrelerinin karşılaştırılabilmesi için mevsim, besi başı ağılığı ve besi süresi bakımından standardizasyon yapılmış (Düzgüneş ve Akman, 1995) ve bunun için aşağıdaki eşitlikten yararlanılmıştır (Eşitlik 3). Eşitlikte standart değer olarak mevsim için ilkbahar, besi başı ağırlığı için $200 \mathrm{~kg}$ ve besi süresi için de 300 gün standart değer olarak kabul edilmiştir.

$$
\begin{aligned}
Y_{i j s}= & Y_{i j}+\left(a_{s}-a_{i}\right)+b_{Y X}\left(X_{s}-X_{i j}\right)+b_{Y Z}\left(Z_{s}-\right. \\
& \left.Z_{i j}\right)+e_{i j}
\end{aligned}
$$

Burada;

$Y_{i j s}:$ i. mevsimde besiye alınan j. hayvanın üzerinde durulan verim parametresi bakımından standardize edilmiş değeri,

$Y_{\mathrm{ij}}$ : i. mevsimde besiye alınan j. hayvanın üzerinde durulan verim parametresi 
bakımından değeri,

$a_{s}$ : Standart olarak seçilen mevsimin (ilkbahar) etki miktarını,

$a_{i}: \quad$ i. mevsimin etki miktarını,

$X_{S}:$ Standart kabul edilmiş besi başı ağırlığını (200 kg),

$X_{i j}$ : i. mevsimde besiye alınan j. hayvanın besi başı ağırlığını,

$Z_{S}: \quad$ Standart kabul edilmiş besi süresini (300 gün),

$Z_{i j}$ : i. mevsimde besiye alınan j. hayvanın beside tutulduğu süreyi,

$b_{Y X}$ ve $b_{Y Z}$ : Regresyon katsayılarını,

$e_{i j}$ : Tesadüfi çevre faktörlerinin etki miktarını (Hata)

ifade etmektedir.

Bunlara ilişkin ırk bazında besi sonu ağırlığı, yağsız sıcak karkas ağırlığı, karkas randımanı ve günlük canlı ağırlık artışı için varyans analizleri yapılmıştır. Bir diğer deyişle ırk bazında besi performansları araştırımıştır. Analiz sonuçlarına göre hangi ırkın besi performansının daha iyi olduğu tespit edilmiştir. Grupların istatistiksel olarak karşılaştırılması Tukey (1991) çoklu karşılaştırma testi ile yapılmıştır.

Tüm istatistiksel değerlendirmelerde SAS (2000) istatistik paket programından yararlanılmıştır.

\section{Araştırma Bulguları ve Tartışma}

Günlük canlı ağırlık artışı ele alındığında (Çizelge 2), Siyah Alaca ırkı sığırlar ile karşılaştırılan Esmer ırkı sığırlar ve Yerli Kara melezlerinin ortalamaları arasındaki farklılıklar önemli bulunmuş $(P<0.05)$, buna karşılık Siyah Alaca ırkı sığırlar günlük canlı ağılık artışı açısından Esmer melezleri, Simentaller, Simental melezleri ve Şarole ırkı sığırlar ile karşılaştırıldığında ise ortalamalar arasında saptanan farklılıklar önemsiz $(P>0.05)$ olarak tespit edilmiştir. Siyah Alaca melezleri günlük canlı ağırlık artışı bakımından Esmer melezleri, Simental ırkı sığırlar, Simental melezleri, Şarole ırkı sığırlar ve Yerli Kara melezleri ile karşılaştırıldığında ortalamalar arasındaki farklılıklar önemli bulunmuştur $(P<0.05)$. Bununla birlikte Siyah Alaca melezleri ile Esmer ırkı sığırlar arasında günlük canlı ağırlık artışı bakımından saptanan ortalamalar arasındaki farklılıklar ise önemsizdir ( $P>0.05)$. Esmer ırkı sığırlar ile Yerli Kara melezleri arasında günlük canlı ağırlık artışı açısından ortalamalar arasındaki farklılıklar önemli iken ( $P<0.05)$, günlük canlı ağırlık artışı bakımından Esmer ırkı sığırların Simental, Simental melezleri ve Şarole ırkı sığırlar ile karşılaştırılması sonucu saptanan ortalamalar arası farklılıklar önemsizdir ( $P>0.05)$.

Günlük canlı ağırlık artışı açısından Esmer melezleri ile Simental ırkı sığırlar arasında saptanan ortalamalar arası farklılıklar önemli iken $(P<0.05)$, Esmer melezleri ile karşılaştırılan Simental melezleri, Yerli Kara melezleri ve Şarole ırkı sığırların ortalamaları arasında saptanan farklılıklar önemsiz bulunmuştur ( $P>0.05)$. Simental ırkı sığırlar ile Şarole ırkı sığırlar arasında günlük canlı ağırlık artışı açısından saptanan ortalamalar arası farklılıklar önemli iken $(P<0.05)$, Simental ırkı sığırlar ile Yerli Kara melezleri arasındaki ortalamalar arası farklılıklar istatistiksel olarak önemsizdir ( $P>0.05)$. Günlük canlı ağırlık artışı açısından Simental melezleri ile Esmer ırkı sığırlar arasında saptanan ortalamalar arası farklılıklar önemli bulunmuş iken $(P<0.05)$, Simental melezlerinin Yerli Kara melezleri ve Şarole ırkı sığırlar ile arasında saptanan ortalamalar arası farklılıklar önemsiz bulunmuştur ( $P>0.05)$. Yerli Kara melezlerinin günlük canlı ağırlık artışı açısından Simental ırkı sığırlar ve Esmer ırkı sığırlar ile arasında saptanan ortalamalar arası farklılıklar önemli bulunurken $(P<0.05)$, Yerli Kara melezleri ile Şarole ırkı arasındaki farklılıklar ise önemsizdir $(P>0.05)$.

Araştırma sonucunda kesim ağırlığı bakımından Siyah Alaca ırkı sığırlar ve Siyah Alaca melezleri arasındaki, Esmer ırkı sığırlar ile Esmer melezleri arasındaki ve Simental ırkı sığırlar ile Simental melezleri arasındaki ortalamaların farkı önemsiz bulunmuştur ( $P>0.05)$. Bununla birlikte Siyah Alaca ırkı sığırlarla Esmer ve Yerli Kara melezleri arasındaki ortalamaların farkı önemli bulunmuştur 
Çizelge 2. Standardize edilmiş verilerle ırklara göre elde edilen günlük canlı ağırlık artışları ve kesim ağırlıklarına ilişkin sonuçlar

Table 2. Daily live weight gains and slaughter weights results obtained by breeds with standardized data set

\begin{tabular}{lccc}
\hline & & $\begin{array}{c}\text { GCAA }(\mathrm{kg}) \\
(\bar{X} \pm \mathrm{S} \bar{x})\end{array}$ & \multicolumn{1}{c}{$\begin{array}{c}\text { Kesim ağırlığı (kg) } \\
(\bar{X} \pm S \bar{x})\end{array}$} \\
\cline { 1 - 3 } Irk & $\mathrm{N}$ & $1.24 \pm 0.027^{\mathrm{ba}}$ & $527.01 \pm 7.868^{\mathrm{ba}}$ \\
\cline { 3 - 4 } SAM & 113 & $1.22 \pm 0.032^{\mathrm{bac}}$ & $522.78 \pm 9.575^{\mathrm{bac}}$ \\
E & 71 & $1.12 \pm 0.015^{\mathrm{d}}$ & $491.27 \pm 4.705^{\mathrm{d}}$ \\
EM & 160 & $1.17 \pm 0.021^{\mathrm{bdc}}$ & $507.35 \pm 6.602^{\mathrm{bdc}}$ \\
S & 92 & $1.26 \pm 0.019^{\mathrm{a}}$ & $533.55 \pm 5.799^{\mathrm{a}}$ \\
SM & 144 & $1.21 \pm 0.021^{\mathrm{bac}}$ & $519.58 \pm 6.361^{\mathrm{bac}}$ \\
YKM & 115 & $1.15 \pm 0.026^{\mathrm{dc}}$ & $502.15 \pm 8.253^{\mathrm{dc}}$ \\
Ş & 80 & $1.22 \pm 0.036^{\mathrm{bac}}$ & $522.86 \pm 11.996^{\mathrm{bac}}$ \\
\hline
\end{tabular}

SA: Siyah Alaca, SAM: Siyah Alaca Melezi, E: Esmer, EM: Esmer Melezi, S: Simental, SM: Simental Melezi, YKM: Yerli Kara Melezi, Ş: Şarole, GCAA: Günlük canlı ağırlık artışı. Aynı sütunda aynı harf taşıyan grup ortalamaları arasındaki farklar istatistiksel olarak önemsizdir ( $P>0.05)$.

$(P<0.05)$. Diğer tataftan, Siyah Alaca ırkı sığırlar ile Esmer melezleri, Simental, Simental melezleri ve Şarole ırkı sığırların kesim ağılığı bakımından karşılaştırılması sonucunda ise ortalamalar arasında saptanan farklılıklar önemsiz bulunmuştur ( $P>0.05)$.

Siyah Alaca melezleri ile Esmer ırkı sığırlar arasındaki kesim ağılığı bakımından saptanan farklılıklar önemli $(P<0.05)$ bulunmuşken (Çizelge 2), Siyah Alaca melezlerinin, Esmer melezleri, Simentaller, Simental melezleri, Yerli Kara melezleri ve Şarole ırkı sığırlar ile karşılaştırılması sonucunda kesim ağırlığı bakımından ortalamalar arasında saptanan farklılıklar önemsiz bulunmuştur $(\mathrm{P}>0.05)$. Esmer ırkı sığırların Simental ırkı sığırlar, Simental melezleri ve Şarole ırkı sığırlar ile karşılaştırılması sonucunda kesim ağırlığına ilişkin ortalamaların farklılıkları önemli iken $(\mathrm{P}<0.05)$, Esmer ırkı sığırların Yerli Kara melezleri ile arasında kesim ağırlığı bakımından saptanan ortalamalar arası farklılıklar önemsiz bulunmuştur ( $P>0.05)$.Esmer melezleri Simental ırkı sığırlar ile kesim ağırlı̆ı bakımından karşılaştırıldığında ortalamalar arasındaki farklılıklar önemli bulunmuşken $(P<0.05)$, Esmer melezleri ile kesim ağırlığı bakımından kıyaslanan Simental melezleri, Yerli Kara melezleri ve Şarole ırkı sığırların ortalamaları arasındaki farklılıklar önemsizdir ( $P>0.05)$. Benzer şekilde Yerli Kara melezleri ile Şarole ırkı sığırlar arasında ise kesim ağırlığı bakımından saptanan ortalamalar arası fark önemsizdir $(\mathrm{P}<0.05)$.

Yağsız sıcak karkas ağırlıkları ele alındığında (Çizelge 3), Siyah Alaca ırkı sığırlar ile Siyah Alaca melezleri, Esmeler ile Esmer melezleri, Simental ırkı sığırlar ile Simental melezi sığır ırklarına ilişkin ortalamalar arasındaki fark önemsiz bulunmuştur (P>0.05). Diğer taraftan, Siyah Alaca ırkı sığırlar ile Esmer ırkı sığırların ortalamaları arasında saptanan farklılıklar önemli bulunmuştur $(P<0.05)$. Fakat Siyah Alaca ırkı sığırlarla Esmer melezi, Simental, Simental melezi, Yerli Kara melezi ve Şarole ırkı sığırlar arasındaki ortalamaların farklılıkları önemsizdir ( $P>0.05)$.

Öte yandan, Siyah Alaca melezleri ile Esmer ırkı sığırlar arasında yağsız sıcak karkas bakımından saptanan ortalama farklılıkları önemli bulunmuştur $(P<0.05)$. Ancak Siyah Alaca melezleri yağsız sıcak karkas bakımından Esmer melezleri, Simental ırkı sığırlar, Simental melezleri, Yerli Kara melezleri ve Şarole ırkı sı̆̆ırlar ile karşılaştırıldığında ortalamalar arasındaki farklılıklar önemsiz bulunmuştur $(P>0.05)$. Esmer ırkı sığırların Simental ırkı sığırlar ve Şarole ırkı sığırlar ile yağsız sıcak karkas bakımından karşılaştıııldığında saptanan ortalama arasındaki farklılıklar önemli iken $(P<0.05)$, Esmer ırkı sığırların Simental melezleri ve Yerli Kara melezleri ile karşılaştırıldığında ortalamaların farklılıkları önemsiz bulunmuştur $(P>0.05)$. 
Çizelge 3. Standardize edilmiş verilerle ırklara göre elde edilen yağsız sıcak karkas ağırlı̆̆ı ve karkas randımanına ilişkin sonuçlar. Table 3. Dressing percentage and hot carcass weight results obtained by breeds with standardized data.

\begin{tabular}{|c|c|c|c|}
\hline Irk & $\mathrm{N}$ & $\begin{array}{l}\text { YSK (kg) } \\
(\bar{X} \pm \mathrm{S} \bar{x})\end{array}$ & $\begin{array}{l}\text { Karkas randımanı (\%) } \\
\qquad(\bar{X} \pm \mathrm{S} \bar{x})\end{array}$ \\
\hline SA & 113 & $321.01 \pm 4.805^{b a}$ & $0.55 \pm 0.002^{b}$ \\
\hline SAM & 71 & $323.64 \pm 6.152^{\text {ba }}$ & $0.56 \pm 0.003^{a}$ \\
\hline $\mathrm{E}$ & 160 & $306.21 \pm 2.783^{c}$ & $0.56 \pm 0.003^{a}$ \\
\hline EM & 92 & $315.26 \pm 3.861^{b c}$ & $0.56 \pm 0.002^{\mathrm{ba}}$ \\
\hline S & 144 & $330.51 \pm 3.544^{a}$ & $0.56 \pm 0.001^{b a}$ \\
\hline SM & 115 & $318.85 \pm 3.985^{\mathrm{bac}}$ & $0.56 \pm 0.002^{\mathrm{ba}}$ \\
\hline YKM & 80 & $311.24 \pm 4.974^{b c}$ & $0.56 \pm 0.002^{\mathrm{ba}}$ \\
\hline Ş & 41 & $323.22 \pm 7.333^{b a}$ & $0.56 \pm 0.003^{\mathrm{ba}}$ \\
\hline
\end{tabular}

SA: Siyah Alaca, SAM: Siyah Alaca Melezi, E: Esmer, EM: Esmer Melezi, S: Simental, SM: Simental Melezi, YKM: Yerli Kara Melezi, Ş: Şarole, YSK: Yağsız sıcak karkas ağırlığı. Aynı sütunda aynı harfi taşıyan grup ortalamaları arasındaki farklar istatistiksel olarak önemsizdir $(P>0.05)$.

Simental ırkı sığırlar ile karşılaştırıldığında ortalamalar arasındaki farklılıklar önemli iken $(P<0.05)$, Esmer melezi hayvanlar Simental melezleri, Yerli Kara melezleri ve Şarole ırkı sığırlar ile karşılaştırıldığında ortalamalar arasındaki farklılıklar önemsiz bulunmuştur ( $P>0.05)$. Simental ırkı sığırlar ile Yerli Kara melezi sığırlar arasında Yağsız sıcak karkas bakımından oluşan ortalamalar arası farklılıklar önemli bulunmuş iken $(P<0.05)$, Simental ırkı sığırlar ile Şarole ırkı sığırların ortalamaları arasındaki farklılıklar önemsizdir ( $P>0.05)$. Yağsız sıcak karkas bakımından Yerli Kara melezleri ve Şarole ırkı sığırların ortalamaları arasındaki farklılıklar önemli bulunmuştur $(P<0.05)$. Son olarak yağsız sıcak karkas bakımından simental melezleri ile araştırmada kullanılan diğer ırklar ortalamalar arasında saptanan farklılıklar önemsizdir ( $P>0.05)$.

Irklar karkas randımanına göre
değerlendirildiğinde ise (Çizelge 3) $0.55 \pm 0.002 \mathrm{~kg}$ ile Simental ırkı sığırların en düşük verime sahip ırk olduğu görülmüştür. Siyah Alaca melezleri, Esmer ırkı sığırlar ve Şarole ırkı sığırlar $0.56 \pm 0.003 \mathrm{~kg}$ ile karkas randımanı bakımından birbirilerine eşit iken, Siyah Alaca ırkı sığırlar ise Esmer melezleri, Yerli Kara melezleri ve Simental melezleri $0.56 \pm 0.002 \mathrm{~kg}$ ile karkas randımanı bakımından birbirilerine eşittir. Karkas randımanı ele alındığında Siyah Alaca ırkı sığırlar ve Esmer ırkı sığırların ortalamaları arasındaki farklılıklar önemli bulunmuş iken $(P<0.05)$, diğer ırkların karkas randımanında ilişkin ortalamaları arasındaki farklılıkları istatistiksel olarak önemsizdir(P>0.05).
Bu çalışmada $1.22 \pm 0.026 \mathrm{~kg}$ olarak tespit edilen Şarole ırkına ait günlük canlı ağırlık artış değeri Sağsöz ve ark. (2005)'nın elde ettikleri değerlerden yüksek bulunmuştur. Araştırmacılar kendi araştırmalarında Şarole ırkı sığırların günlük canlı ağırlık artış değerini $0.885 \pm 0.05$ olarak tespit etmişlerdir. Bu farklılıklara çalışmada kullanılan yem içerikleri, çalışmanın yapıldığı bölgenin iklim koşulları, ırkların besiye alınma yaşları ve beside tutulma süreleri gibi farklılıkların neden olduğu düşünülmektedir.

Aslan (2009) besi sonu ağırlığını, sıcak karkas ağırlığını ve günlük canlı ağırlık artışını Siyah Alaca, Esmer ve Simental ırkı sığırlar için sırasıyla 557.59, 551.04 ve $562.11 \mathrm{~kg} ; 328.10,315.85$ ve $324.81 \mathrm{~kg}$ ve 1107.27, 1073.21 ve $1139.09 \mathrm{~g}$ olarak bildirmiştir. Araştırmacının çalışmasında besi sonu ağırlıkları bu çalışmadan yüksek olmakla birlikte günlük canlı ağırlık artışı bakımından bu çalışmadan düşük değerler almıştır. Sıcak karkas ağırlığı için ise ait bu çalışmadan elde edilen değerler Siyah Alaca ve Esmerler için araştırmacının çalışmasındaki değerlerden düşük Simental için ise yüksektir.

Alpan (1972) Simental ırkı için birçok özellik bakımından Esmer ırkından daha düşük değerler gösterdiğini belirtmekle birlikte bu çalışmada ise Simental ırkı, Esmer ırkına göre günlük canlı ağırlık artışı, yağsız sıcak karkas ağırlığı ve kesim ağırlığı bakımından daha yüksek değerler göstermiştir. Araştırma sonucu arasındaki farklılıklara hayvanların besiye alınma yaşlarının, yetiştirildikleri bölgelerin ve rasyon farklılıklarının sebep olması muhtemeldir. 
Arpacık ve ark. (1988), çalışmalarında Siyah Alaca ırkı sığırların canlı ağırlık artış değerlerini1078 \pm 80 - $1225 \pm 30 \mathrm{~g}$ olarak tespit etmişlerdir. Bu sonuçlar bu çalışmadan elde edilen

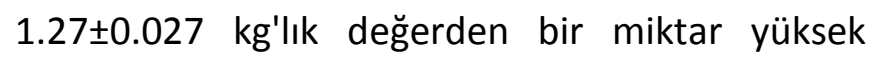
bulunmuştur. Bu farklılıklara besiye başlangıç ağırlıklarındaki farklılıklar sebep olmuş olabilir.

Bu çalışmadan elde edilen Siyah Alaca ırkına ait günlük canlı ağırlık artışı ve yağsız sıcak karkas ağırlığı değerleri Güngör ve ark. (2004)'nın Siyah Alaca ırkına ait günlük canlı ağırlık artışı ve yağsız sıcak karkas ağırlığı için sırasıyla $1.05 \pm 0.04 \mathrm{~kg}$ ve $286.78 \pm 7.70 \mathrm{~kg}$ olarak bildirdiği değerlerden yüksektir.

Bu çalışmada $1.12 \pm 0.015 \mathrm{~kg}$ olarak tespit edilen Esmer ırkına ait günlük canlı ağırlık artışı Akbulut ve Tüzemen (1994)'in 8 - 12 aylık yaşlardaki Esmer ırkına ait $0.909 \pm 0.08 \mathrm{~kg}$ olarak tespit ettiği ve Tüzemen (1995)'in bildirdiği birinci grubun 10 aylık Esmer ırkı sığırlarından elde ettiği $1.010 \pm 0.44 \mathrm{~kg}$ günlük canlı ağırlık artış değerlerinden yüksektir. Fakat aynı grubun 15 aylık Esmer ırkı sığırlarından elde edilen $1.165 \pm 0.026 \mathrm{~kg}$ günlük canlı ağırlık artışı değerlerinden ve ikinci grupta ise sırasıyla 10 ve 15 aylık Esmer ırkı sığırların günlük canlı ağırlık artış değerleri olarak bildirilen $1.165 \pm 0.026 \mathrm{~kg}$ ve $1.143 \pm 0.028$ kg'dan daha düşük bulunmuştur. Bu farklılığa çalışmaların gerçekleştirildiği barınaklardaki farklılıklar, yaş, iklim, yem gibi etmenler sebep olmuş olabilir.

$\mathrm{Bu}$ çalışmada Esmer ve Siyah Alaca ırkları için $1.12 \pm 0.015 \mathrm{~kg}$ ve $1.24 \pm 0.024 \mathrm{~kg}$ olarak tespit edilen günlük canlı ağılık artışı değerleri Çatıkkaş (2015) tarafından bildirilen farklı gruplara ayrılmış ve birinci gruptaki Esmer ve Siyah Alaca ırkı sığırlara ait günlük canlı ağırık artışı 1.35 $\pm 0.06,1.34 \pm 0.05$ kg olarak ve ikinci gruptaki $1.62 \pm 0.04$ ve $1.57 \pm 0.05$ $\mathrm{kg}$ olarak tespit edilmiş değerlerden düşüktür. Bununla birlikte araştırmacıların çalışmalarındaki birinci gruba ait Esmer ve Siyah Alaca ırkı sığırların sıcak karkas ağırlıkları $289.40 \pm 3.69$ ve $279.44 \pm 3.28$ $\mathrm{kg}$ olarak tespit edilmiştir ve bu çalışmadan elde edilen $306.21 \pm 2.783$ ve $321 \pm 4.805$ değerlerinden düşük bulunmuştur. İkinci gruba ait sıcak karkas ağırlıkları ise Esmer ırkı sığırlarda $309.25 \pm 3.45 \mathrm{~kg}$ ile bu çalışmadaki Esmer ırkından yüksek,
$304.36 \pm 4.14$ kg ile Siyah Alaca ırkı sığırlardan düşük değerler almıştır.

Bu çalışmada $1.24 \pm 0.024 \mathrm{~kg}$ olarak tespit edilen Siyah Alaca ırkı sığırlara ait günlük canlı ağırlık artışı Akbulut ve Tüzemen (1994)'in elde ettiği değerlerden yüksektir. Araştırmacılar yapmış oldukları çalışmalarında 8-12 aylık yaşlardaki Siyah Alaca ırkı sığırlarda günlük canlı ağırlık artışlarını $0.941 \pm 0.04 \mathrm{~kg}$ olarak tespit etmişlerdir.

Gürbüz ve ark. (1998) enerji düzeyi 600 ve 700 nişasta birimi olan rasyonla beslenen Siyah Alaca ırkı sığırlar için günlük canlı ağırlık artışını 1.190 kg ve $1.244 \mathrm{~kg}$ olarak bildirmiş olup söz konusu değerler bu çalışmadan düşüktür. Bununla birlikte enerji düzeyi 650 nişasta birimi rasyonla beslenen Siyah Alaca ırkı grup ise 1.257 kg günlük canlı ağırlık artışı sağlayarak bu çalışmadan yüksek değer almıştır. Bu farklılıklara rasyon içerikleri, besiye alınma yaşları ve besi sürelerindeki farklılıklar sebep olmuş olabilir.

$\mathrm{Bu}$ çalışmada Siyah Alaca ırkı sığırlar için $1.24 \pm 0.024 \mathrm{~kg}$ olarak hesaplanan günlük canlı ağırlık artışı değerleri ilıü ve Güneş (2002) ile Koç ve Akman (2003) tarafından sırasıyla $1023.6 \mathrm{~g}$ ve $0.964 \pm 0.059$ olarak bildirilen değerlerden yüksektir. Bununla birlikte Koç ve Akman (2003) tarafından yapılan çalışma ağır grup ve hafif grup olmak üzere iki grupla gerçekleştirmiştir. Hafif olarak adlandırılan grup için besi başı ağırlığı $246.4 \pm 13.52 \mathrm{~kg}$, besi sonu ağılığı $476 \pm 26.22 \mathrm{~kg}$, ağır grupta ise besi başı ağırlığı $387.4 \pm 13.06 \mathrm{~kg}$, besi sonu ağırlığı $529.3 \pm 15.25 \mathrm{~kg}$ olarak tespit edilmiştir. Her iki grubun besi sonu ağırlığı bu

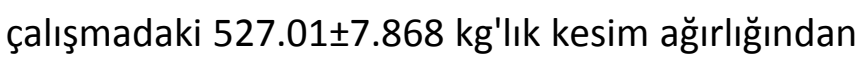
düşük bulunmuşken bu çalışmadaki Siyah Alaca ırkı sığırlara ait $259.45 \pm 4.362$ kg'lık besi başı ağırlığı değeri hafif gruptan yüksek, ağır gruptan düşüktür. Bu farklııklara çalışmaların gerçekleştirildiği çevre şartlarının farkııı̆ı ile besiye alınma yaşının ve beside tutulma sürelerinin farklılıkları sebep olmuş olabilir.

Bu çalışmada Simental ırkına ait 527.01 \pm 7.868 kg olarak saptanan kesim ağırlığı ve $330.5 \pm 3.544$ kg olarak saptanan yağsız sıcak karkas ağırlığı Duru ve Sak (2017)' nin çalışmasından elde edilen 523.4 kg ve 523.4 kg' lık değerlerden yüksek bulunmuş iken 
bu çalışmadan elde edilen $1.26 \pm 0.019 \mathrm{~kg}$ lık günlük canlı ağırlık artışı araştırmacıların 1.3629 kg olarak elde ettiği günlük canlı ağırlık artışı değerinden düşüktür.

Haiger ve Knaus (2010) yaptıkları çalışmalarında Simental ırkı sığırların 660 kg, Siyah Alaca ırkı sığırların ise 565 kg olarak tespit edilen besi sonu ağırlıkları bu çalışmadan elde edilen Simental ırkı sığırlara ve Siyah Alaca ırkı sığırlara ait olan $533.55 \pm 5.8 \mathrm{~kg}$ ve $527.01 \pm 7.87 \mathrm{~kg}$ 'lık kesim ağılıklarından yüksek bulunmuştur. Çalışmalar arasında Simental ırkı sığırlar için 126.45 kg Siyah Alaca ırkı sığırların için ise 37.66 kg'lık bir fark gözlenmiştir. Bu farklılıklara besiye alınma yaşı, yetiştirilme koşullarındaki farklılıklar, bölgenin iklim koşullarında görülen değişimler, yem içeriklerindeki farklılıklar sebep olmuş olabilir. Fakat her iki çalışmada da benzer şekilde Simental ırkı sığırların kesim ağırlığının Siyah Alaca ırkı sığırlardan yüksek olduğu görülmüştür.

\section{Sonuçlar}

Bu çalışmada Şanlıurfa ilinde besi materyali olarak kullanılabilecek Siyah Alaca, Siyah Alaca melezi, Simental, Simental melezi, Esmer, Esmer melezi, Şarole ve Yerli Kara melezi sığır ırklarının besi performansları ve karkas özellikleri incelenmiştir.

Araştırma sonunda kesim ağırlıkları bakımından Simental, Simental melezi, Şarole, Siyah Alaca ve Siyah Alaca melezi ırkı sığırların diğer ırklardan yüksek performans gösterdiği saptanmıştır. Yağsız sıcak karkas randımanı bakımından Simental, Simental melezi, Şarole, Siyah Alaca ve Siyah Alaca melezi diğer ırklardan daha yüksek performans göstermiştir. Günlük canlı ağırlık atışı bakımından Simental, Simental melezi, Şarole, Siyah Alaca ve Siyah Alaca melezi diğer ırklardan yüksek canlı ağırlık artışı göstermiştir. Son parametre olan karkas randımanı bakımından ise Simental, Simental melezi, Şarole, Siyah Alaca melezi, Esmer, Esmer melezi ve Yerli Kara melezleri Siyah Alaca ırkı sığırlardan yüksek performans göstermiştir. Simental ırkı sığırlar kesim ağırlığı, yağsız sıcak karkas ağırlığı ve günlük canlı ağırlık artışı açısından en yüksek değerlere sahip ırk iken Esmer ırkı sığırlar ise tüm bu parametreler açısından en düşük değerlere sahip ırk olarak tespit edilmiştir.

Bu çalışmada etçi ırk olarak adlandırılan Şarole ırkının, Simental ırkı sığırlarla benzer performans göstermesi önemli bir bulgu olarak nitelendirilebilir. Bu sonuç Şanlıurfa koşullarında çevre faktörlerinin yeterli düzeyde tutulması şartıyla kültür ırkı etçi genotiplerinde beside ekonomik olarak kullanılabileceğini göstermektedir. Bununla birlikte bölge koşullarında Angus, Limuzin ve Hereford gibi etçi ırkların üzerinde de benzer araştırmaların yapılması gerektiği söylenebilir.

Bu çalışma Şanlıurfa'daki yetiştiriciler için yol gösterici niteliktedir. Bu çalışma sonucunda karlı bir üretim yapmak isteyen yetiştirici hangi ırkın Şanlıurfa koşullarında kullanılmasının fayda sağlayacağını belirleyebilecektir. Böylece bölge hayvancılığı adına olumlu gelişmeler sağlanabilecektir.

Tüm bu verilerin ışığında Şanlıurfa'da yetiştiricilere üzerinde durulan tüm parametreler göz önünde bulundurulduğunda Simental, Simental melezi, Şarole, Siyah Alaca veya Siyah Alaca melezi sığır ırklarını kullanmaları önerilebilir.

\section{Ekler}

Bu çalışma, HÜBAK tarafından desteklenen (Proje no17118), 2017 yılında tamamlanan Şanlıurfa İlinde Besiye Alınmış Farklı Sığır Irklarında Besi Performansı ve Karkas Özellikleri adlı Yüksek Lisans Tez çalışmasından özetlenmiştir.

$\mathrm{Bu}$ çalışmanın özetlendiği "Şanlıurfa ilinde Besiye Alınmış Farklı Sığır Irklarında Besi Performansı ve Karkas Özellikleri" adlı tez 23/06/2017 tarihinde Harran Üniversitesi Fen Bilimleri Enstitüsü Zootekni Anabilim Dalı' nda yüksek lisans tezi olarak kabul edilmiştir.

Çıkar Çatışması Beyanı: Makale yazarları aralarında herhangi bir çıkar çatışması olmadığını beyan ederler. 


\section{Kaynaklar}

Akbulut, Ö., ve Tüzemen, N. (1994). 8-12 aylık yaşlarda besiye alınan Esmer, Siyah Alaca ve Simental tosunların besi performansı, kesim ve karkas özellikleri. Atatürk Üniversitesi Ziraat Fakültesi Dergisi, 25 (2): 134-144.

Akman, (1998). Pratik Sığır Yetiştiriciliği. Ankara: Türk Ziraat Mühendisleri Birliği Yayını.

Alpan, O. (1972). Esmer, Siyah Alaca ve Simental erkek danalarında besi kabiliyeti ve karkas özellikleri. Ankara Üniversitesi Veterinerlik Fakültesi Dergisi, 19: 388-400.

Anonim, (2013). Şanlıurfa büyükbaş hayvancılık ve hayvansal gıda ürünleri kümelenme yol haritası. Karacadağ kalkınma ajansı. 2013 yılı raporu.

Arpacık, R., Akcan, A., Alpan, O., Ertuğrul, O. ve Aksoy, A. R. (1988), Ankara Üniversitesi Veteriner Fakültesi Dergisi, 35 (1), 124-134.

Aslan, E. (2009). Orta Anadolu şartlarında açıkta besiye alınan siyah alaca, esmer ve simental ırkı sığırların besi performanslarının karşılaştırılması. (Yüksek lisans tezi, Selçuk Üniversitesi, Konya) http://acikerisimarsiv.selcuk.edu.tr:8080/xmlui/bitstr eam/handle/123456789/7611/237239.pdf?sequence $=1$ \&isAllowed $=y$.

Çatıkkaş, E. (2015). Aydın'da yetiştirilen Siyah-Alaca, Esmer ve Simental ırkı sığırlarda karkas ve et kalite özellikleri üzerine bir araştırma. (Yüksek lisans tezi, Adnan Menderes Üniversitesi, Aydın).

Çiçek, H., Cevger, Y., Tandoğan, M., Ve Şahin, E. H. (2010). Montofon Melezi (F1) Sığırlarla Yapılan Beside Optimum Besi Süresinin Tespiti. Kafkas Üniversitesi Veteriner Fakültesi Dergisi, 16 (1): 63-67.

Duru, S. ve Sak, H. (2017). Türkiye' de besiye alınan Simental Aberdeen Angus, Hereford, Limousin ve Charolais ırkı sığırların besi performansı ve karkas özellikleri. Türk Tarım Gıda Bilim ve Teknoloji Dergisi, 5(11): 13831388.

Düzgüneş, O. ve Akman, N. (1995). Varyasyon kaynakları. Ankara üniversitesi Ziraat Fakültesi Yayınları,no:1408. Ders kitabı: 406, VII+146 s. Ankara.

Güngör, M., Alçiçek, A., Tümer, S. ve Önenç, A. (2004). Siyah Alaca ve farklı etçi ırk melezlerinin besi performanslarının araştırılması. Anadolu, J. of AARI 14 (1), $27-40$.

Haiger, A. and Knaus, W. (2010). A comparison of dualpurpose Simmental and Holstein Friesian dairy cows in milk and meat production: 2nd comn. Fattening and slaughter performance using domestic protein feed stuffs. Zuchtungskunde 82(6): 447-454s.

İlgü, E., Güneş, H. (2002). Siyah-Alaca ırkından erkek sığırların özel işletme koşullarındaki besi performansları üzerinde araştırmalar. İstanbul Üniversitesi Veterinerlik Fakültesi Dergisi, 28 (2): 313-335.

Kızıl, H. K. ve Aydoğan, M. (2014). Türkiye'deki başlıca sığır ırklarının kesim ve karkas özelliklerinin MANOVA ve çok boyutlu ölçüm tekniği kullanılarak değerlendirilmesi. Erciyes Üniversitesi Veterinerlik Fakültesi Dergisi, 11(1): 15.

Koç, A. ve Akman, N. (2003). Farklı ağılıkta besiye alınan ithal edilmiş Siyah Alaca tosunların besi gücü ve karkas özellikleri. Hayvansal Üretim, 44(1): 26-36.

Sağsöz, Y., Çoban, Ö., Laçin, E., Sabuncuoğlu, N., ve Yıldız, A. (2005). Esmer ve Şarole x Esmer danaların besi performansı ve karkas özellikleri. Atatürk Üniversitesi Ziraat Fakültesi Dergisi, 36(2): 163-169.

SAS Insttute (2000). SAS User's guide: Statistics. Version 8 ed. SAS Institute. Gary. NC.

Şekerden, Ö. ve Özkütük, K. (1997). Büyükbaş hayvan yetiştirme. Çukurova Üniversitesi, Ziraat Fakültesi, Adana, 122s.

Toprak, N., N., Yavaş, ì. ve Bilgel, C. (2018). Besi sığırı rasyonlarında tamamlayıcı yem olarak farklı şekillerde işlenmiş arpa ve mısır kullanımının performans, bazı biyokimyasal parametreler ile serum laktat ve bikarbonat düzeyi üzerine etkileri. Harran Tarım ve Gıda Bilimleri Dergisi, 22(2): 275-283.

Tukey JW. (1991). The Philosophy of Multiple Comparisons. Statistical Science, 6(1): 100-16

TÜiK,(2017).http://www.tuik.gov.tr/PreTablo.do?alt_id=100 2.

Tüzemen, N. (1995). Farklı yaş ve farklı barındırma sistemlerinde Esmer ırkı tosunların besi performansları. Atatürk Üniversitesi Ziraat Fakültesi Dergisi, 26 (1): 9 - 20. 